\title{
Antifungal Potency of Foeniculum vulgare Seed Extract
}

\section{Nida Tabassum Khan*}

Department of Biotechnology, Faculty of Life Sciences and Informatics, Balochistan University of Information Technology Engineering and Management Sciences, (BUITEMS), Quetta, Pakistan

\begin{abstract}
Foeniculum vulgare belongs to family Apiaceae and is also called by the name of fennel. Agar disc diffusion method was used to determine the antifungal activity of its seed extracts in water and methanol against a number of pathogenic fungi. Methanolic extract of fennel seeds was less effective against test fungi as compared to its aqueous extract. However in case of Candida species, both types of extracts were found to be effective.
\end{abstract}

Keywords: Apiaceae; Fennel; Seed extract

\section{Introduction}

Foeniculum vulgare is a perennial herb that belongs to the family Apiaceae. Traditionally, it is used as an antiseptic, carminative, digestive, diuretic, and expectorant agent. Foeniculum vulgare is also known as fennel and is mostly found in southern Europe and the Mediterranean region. Nowadays, it occupies a large area in the temperate and tropical regions of the world [1]. Foeniculum vulgare plants have hollow branches with an average height of $2.5 \mathrm{~m}$. Its leaves are finely dissected with thread like segments that are about $0.5 \mathrm{~mm}$ in width. The flowers are positioned at the terminals carrying seeds that are about $4-10 \mathrm{~mm}$ in length [2]. Foeniculum vulgare leaves and its fruit are mainly used as ingredients in cosmetics and as flavoring substances for fish and meat to give them a strong aroma and taste [3]. It's essential oil, which is produced by steam distillation of dried fruits, is used for flavoring purposes in Western countries [4]. Foeniculum vulgare seed and bark extracts have been reported to exhibit antifungal effect against candida species by inhibiting mycelial growth and germination of Sclerotinia sclerotiorum [5,6]. Thus could be used as effective bio fungicide against phytopathogenic fungi [7]. Besides fennel seed possess anticancer property anti-inflammatory, antimicrobial activity and antioxidant activities $[5,8,9]$. Foeniculum vulgare seed extract has antifungal activity against various fungal species such as Candida albicans, species of Aspergillus and dermatophytes [10]. However, very little information is available on the antimicrobial activity of fennel seed extract in in vitro. So the purpose of this research work was to demonstrate and evaluate the antifungal potency of Foeniculum vulgare seed extracts against different pathogenic fungi.

\section{Materials and Methods}

\section{Foeniculum vulgare seed extract preparation}

Foeniculum vulgare seeds were bought from the local market, Satellite town Quetta. Seeds were washed with distilled water twice and then were dried at $40^{\circ} \mathrm{C}$. Foeniculum vulgare seeds were milled into a fine powder using a grinder.

\section{Foeniculum vulgare seed aqueous and alcoholic extract preparation}

For the formation of alcoholic and aqueous seed extract, $5 \mathrm{~g}$ of milled seed powder was weighed accurately and suspended in $50 \mathrm{ml}$ of methanol and distilled water overnight, separately (Figure 1). The flasks were shaken for three hours and then filtered through Whatman No.1 filter paper. The filtrate was centrifuged at $5000 \mathrm{rpm}$ for 5 to $10 \mathrm{~min}$. The final concentration of each extracts was fixed to about $100 \mathrm{mg} / \mathrm{ml}$.

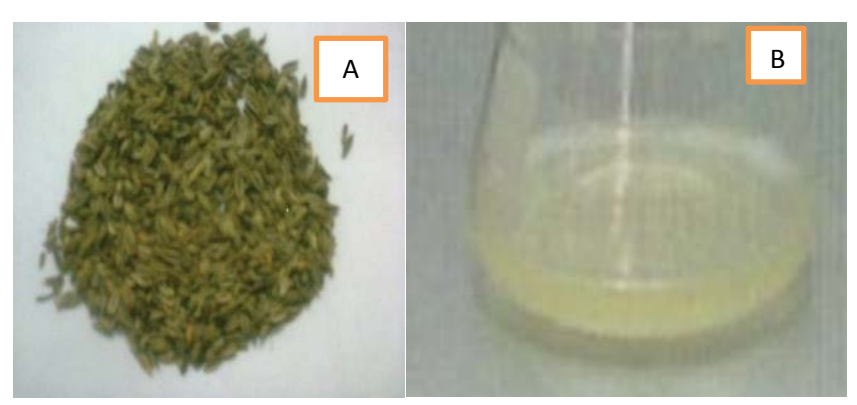

Figure 1: Foeniculum vulgare seeds extract. A: Seeds, B: Extract.

\section{Disc diffusion method}

Antifungal activity of aqueous and methanolic extract was individually tested against a number of pathogenic fungi using disc diffusion method. Already prepared cultures of test fungi were maintained at $32^{\circ} \mathrm{C}$ by subsequent subculturing. Agar surface (YM agar) was inoculated with Candida glabrata, Aspergillus flavus, Candida albicans, Candida parapsilosis, Candida tropicalis Candida krusei, Alternaria alternata and Mucor rouxii.

\section{Sterile discs preparation}

$1 \mathrm{~cm}$ sized sterilized discs were impregnated with different concentration of alcoholic and aqueous seed extract $(20 \mu \mathrm{L}, 40 \mu \mathrm{L}, 60 \mu \mathrm{L}$ and $80 \mu \mathrm{L}$ ) and placed on agar surface, incubated for $48 \mathrm{~h}$ at $37^{\circ} \mathrm{C}$ (Figure 2). Presence or absence of inhibition zone around the impregnated discs indicated the antifungal property of the extracts. YM plates with discs impregnated with different concentrations of autoclaved distilled water was taken as control in all experiments.

*Corresponding author: Department of Biotechnology, Faculty of Life Sciences and Informatics, Balochistan University of Information Technology Engineering and Management Sciences,(BUITEMS),Quetta, Pakistan, Tel: 03368164903; E-mail: nidatabassumkhan@yahoo.com

Received September 09, 2017; Accepted September 29, 2017; Published October 09, 2017

Citation: Khan NT (2017) Antifungal Potency of Foeniculum vulgare Seed Extract. J Tissue Sci Eng 8: 207. doi: 10.4172/2157-7552.1000207

Copyright: () 2017 Khan NT. This is an open-access article distributed under the terms of the Creative Commons Attribution License, which permits unrestricted use, distribution, and reproduction in any medium, provided the original author and source are credited. 




Figure 2: Disc diffusion method containing alcoholic and aqueous seed extract impregnated discs.

\begin{tabular}{|c|c|c|c|}
\hline \multirow{2}{*}{ S. No. } & \multirow{2}{*}{ Names } & Aqueous extract & Methanolic extract \\
\hline & & Inhibition zone & Inhibition zone \\
\hline 1 & Candida glabrata & + & + \\
\hline 2 & Candida krusei & - & - \\
\hline 3 & Candida albicans & + & + \\
\hline 4 & Candida parapsilosis & + & - \\
\hline 5 & Candida tropicalis & + & + \\
\hline 6 & Aspergillus flavus & - & - \\
\hline 7 & Alternaria alternata & + & - \\
\hline 8 & Mucor rouxii & - & + \\
\hline $\begin{array}{l}(+) \text { indica } \\
(-) \text { indicat }\end{array}$ & $\begin{array}{l}\text { he inhibition of the fur } \\
\text { o inhibition of fungal }\end{array}$ & $\begin{array}{l}\text { gl growth } \\
\text { wth }\end{array}$ & \\
\hline
\end{tabular}

Table 1: Observed antifungal activity based on the presence or absence of inhibition zone.

\section{Results}

Foeniculum vulgare seed extracts were evaluated for their antifungal (Table 1).

\section{Discussion}

Several studies revealed that essential oil extracted from fennel seed act as effective antimicrobial agent [11]. But reported research related to determine the antifungal activity of fennel seed extract is scanty. So in this particular study, we have determined he antifungal activity of fennel seed extracts in water and methanol. The anti-fungal activity of fennel seed aqueous extract is due to the presence of secondary metabolites such as flavonoid, phenols, aglycones, glycosides, hydroxyl-cinnamic acid derivatives and anethole [12,13]. The phytochemical toxicity effect of fennel seed extracts on pathogens includes protein inhibition by oxidation involving sulfhydryl groups or by means of non-specific interactions. The obtained results clearly indicates that aqueous fennel seed extract showed effective inhibition of Alternaria alternata fungus while on the other hand its methanolic extract was ineffective against this fungus. The possible reason for this is due to the polar nature of the water, the chemical constituents of the extract such as flavonoids were very soluble in water. Therefore, retained its antimicrobial (antifungal) properties during the extraction process [14]. But in case of Aspergillus flavus and Mucor roxuii both the extracts were completely ineffective as indicted by the absence of inhibition zone. This may be due to intrinsic biological and morphological features of species used in the study. However it is reported before that the aqueous leaf extract of fennel is a good inhibitor of A. alternata, A. brassicola [15], Curvularia lunata and Fusarium oxysporum [16]. Methanolic extract inhibited Mucor roxuii growth but no inhibition zone was observed in agar plates inoculated with Aspergillus flavus and Alternaria alternata. The supporting reason for this is the decreased solubility and volatility of its chemical constituents during organic solvent based extraction process. But the antimicrobial activity of these active compounds are greatly influenced and affected by the environmental conditions under which they are extracted and also the parts of the plant from where they are obtained $[17,18]$.

\section{Conclusion}

Based on the presence of inhibition zone surrounding the extracts impregnated disc we can conclude that fennel seed extracts could be used in the preparation of an effective antifungal agent with a broad activity spectrum against a number of disease causing fungi. However further studies need to be conducted to isolate the active bio compound from the extracts to understand its chemical composition responsible for the antifungal activity. Furthermore using water base extraction methods provides an easy and cheapest way to obtain extracts with potential antifungal activity.

\section{References}

1. Ferrara MMG (1998) Plantas medicinales del noreste de México. Grupo Vitro

2. Díaz-Maroto MC, Díaz-Maroto Hidalgo IJ, Sánchez-Palomo E, Pérez-Coello $\mathrm{MS}$, et al. (2005) Volatile components and key odorants of fennel (Foeniculum vulgare Mill.) and thyme (Thymus vulgaris L.) oil extracts obtained by simultaneous distillation-extraction and supercritical fluid extraction. J Agric Food Chem 53:5385-5389.

3. Ruberto G, Baratta MT, Deans SG, Dorman H (2000) Antioxidant and antimicrobial activity of Foeniculum vulgare and Crithmum maritimum essential oils. Planta Med 66: 687-693.

4. Husain A (1994) Status report on aromatic \& essential oil-bearing plants in NAM countries. Centre for Science \& Technology of the Non-aligned \& Other Developing Countries, India.

5. Abed KF (2007) Antimicrobial activity of essential oils of some medicinal plants from Saudi Arabia. Saudi J Biol Sci 14: 53-60.

6. Pai MB, Prashant GM, Murlikrishna KS, Shivakumar KM, Chandu GN (2010) Antifungal efficacy of Punica granatum, Acacia nilotica, Cuminum cyminum and Foeniculum vulgare on Candida albicans: An in vitro study. Indian J Dental Res 21: 334-336.

7. Soylu S, Yigitbas H, Soylu EM, Kurt S (2007) Antifungal effects of essential oils from oregano and fennel on Sclerotinia sclerotiorum. J Appl Microbiol 103: 1021-1030.

8. Anand P, Kunnumakara A, Sundaram C, Harikumar K, Tharakan S, et al. (2008) Cancer is a preventable disease that requires major lifestyle changes. Pharm Res 25: 2097-2116.

9. Choi EM, Hwang JK (2004) Anti-inflammatory analgesic and antioxidant activities of the fruit of Foeniculum vulgare. Fitoterapia 75: 557-565.

10. Kwon YS, Choi WG, Kim WJ, Kim WK, Kim MJ, et al. (2002) Antimicrobial constituents of Foeniculum vulgare. Arch Pharm Res 25: 154-157.

11. Parejo I1, Viladomat F, Bastida J, Schmeda-Hirschmann G, Burillo J, et al (2004) Bioguided isolation and identification of the non-volatile antioxidant compounds from fennel (Foeniculum vulgare Mill.) waste. J Agric Food Chem 52: $1890-1897$

12. Kaur GJ, Arora DS (2009) Antibacterial and phytochemical screening of Anethum graveolens, Foeniculum vulgare and Trachyspermum ammi. BMC Complement. Altern Med 30.

13. Ozcan MM, Chalchat JC (2006) Effect of collection time on chemical composition of the essential oil of Foeniculum vulgare ssp. piperitum growing wild in Turkey. Eur Food Res Technol 224: 279-281.

14. Hasan MM, Chowdhury SP, Alam S, Hossain B, Alam MS (2005) Antifungal effects of plant extracts on seed-borne fungi of wheat seed regarding seed germination, seedling health and vigour index. Pak J Biol Sci 8: 1284-1289. 
15. Mughal MA, Khan TZ, Nasir MA (1996) Antifungal activity of some plant extracts. Pak J Phytopat 8: 46-48.

16. Prabha P, Bohra A, Purohit $P$ (2002) Antifungal activity of various spice plants against phyto-pathogenic fungi. Cab Abst 15: 615-617.
17. Oliva M (2008) Antimicrobial activity of medicinal plants from South America; in Botanical medicine in clinical practice. CABI International, Wallingford, UK.

18. Webster, D, Taschereau P, Belland RJ, Sand C, Rennie, RP (2008) Antifungal activity of medicinal plant extracts: Preliminary screening studies. $J$ Ethnopharmacol 115: 140-146. 